\title{
SOEP
}

SOEPapers

on Multidisciplinary Panel Data Research

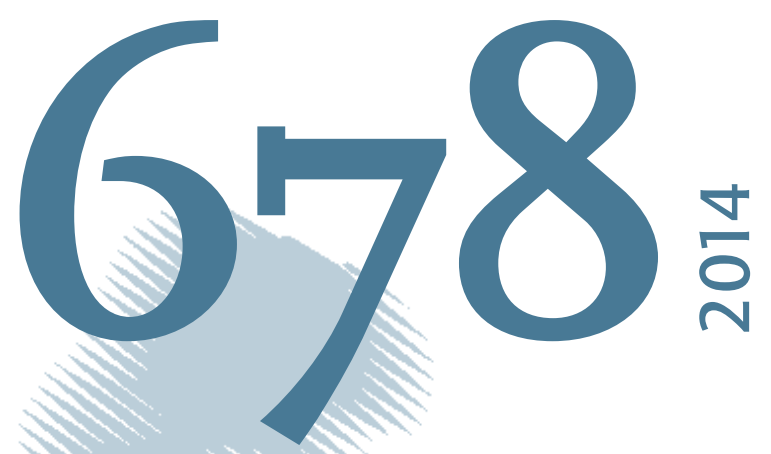

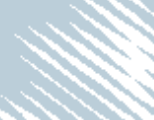
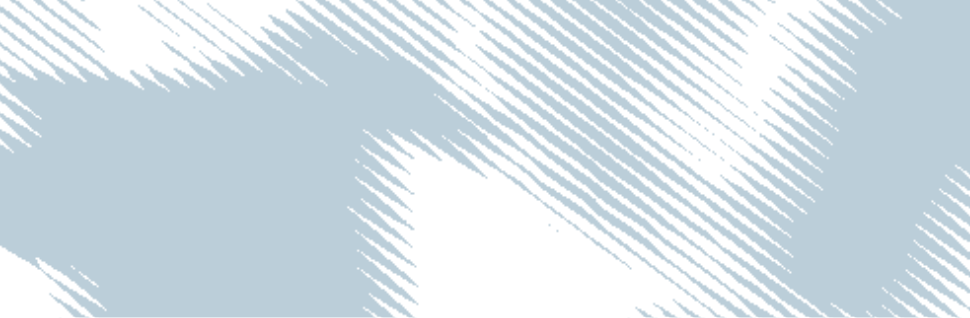

\section{The Effect of Local Crime on Well-Being: Evidence for Germany}




\section{SOEPpapers on Multidisciplinary Panel Data Research}

at DIW Berlin

This series presents research findings based either directly on data from the German SocioEconomic Panel Study (SOEP) or using SOEP data as part of an internationally comparable data set (e.g. CNEF, ECHP, LIS, LWS, CHER/PACO). SOEP is a truly multidisciplinary household panel study covering a wide range of social and behavioral sciences: economics, sociology, psychology, survey methodology, econometrics and applied statistics, educational science, political science, public health, behavioral genetics, demography, geography, and sport science.

The decision to publish a submission in SOEPpapers is made by a board of editors chosen by the DIW Berlin to represent the wide range of disciplines covered by SOEP. There is no external referee process and papers are either accepted or rejected without revision. Papers appear in this series as works in progress and may also appear elsewhere. They often represent preliminary studies and are circulated to encourage discussion. Citation of such a paper should account for its provisional character. A revised version may be requested from the author directly.

Any opinions expressed in this series are those of the author(s) and not those of DIW Berlin. Research disseminated by DIW Berlin may include views on public policy issues, but the institute itself takes no institutional policy positions.

The SOEPpapers are available at

http://www.diw.de/soeppapers

\section{Editors:}

Jürgen Schupp (Sociology)

Gert G. Wagner (Social Sciences, Vice Dean DIW Graduate Center)

Conchita D'Ambrosio (Public Economics)

Denis Gerstorf (Psychology, DIW Research Director)

Elke Holst (Gender Studies, DIW Research Director)

Frauke Kreuter (Survey Methodology, DIW Research Professor)

Martin Kroh (Political Science and Survey Methodology)

Frieder R. Lang (Psychology, DIW Research Professor)

Henning Lohmann (Sociology, DIW Research Professor)

Jörg-Peter Schräpler (Survey Methodology, DIW Research Professor)

Thomas Siedler (Empirical Economics)

C. Katharina Spieß (Empirical Economics and Educational Science)

ISSN: 1864-6689 (online)

German Socio-Economic Panel Study (SOEP)

DIW Berlin

Mohrenstrasse 58

10117 Berlin, Germany

Contact: Uta Rahmann | soeppapers@diw.de 


\title{
The Effect of Local Crime on Well-Being: Evidence for Germany
}

\author{
Christian Krekel \\ DIW Berlin, \\ German Institute for Economic Research, \\ Graduate Center, Mohrenstraße 58, 10117 Berlin, Germany \\ ckrekel@diw.de-www.diw.de/en \\ Marie L. Poprawe \\ ETH Zurich, \\ KOF Swiss Economic Institute, \\ Weinbergstrasse 35, 8092 Zurich, Switzerland \\ poprawe@kof.ethz.ch - www.kof.ethz.ch/en
}

\begin{abstract}
This paper investigates the effect of local crime on well-being in Germany, using data from the German Socio-Economic Panel (SOEP) and a novel data set constructed from official police crime statistics, covering both counties and urban districts for the time period between 1994 and 2012. We find that local area crime has a significantly negative impact on life satisfaction, makes residents worry more frequently, and worry more about crime in Germany. In particular, a 1\% increase in the crime frequency ratio results in a 0.043 standard deviation decrease in life satisfaction. This effect is driven almost exclusively by violent crimes, while property crimes and other crimes have no significant impact on well-being.
\end{abstract}

Keywords:

Crime, Well-Being, Germany

$J E L$ :

I31, K42, R50 


\section{Introduction}

Crime has been argued to discourage investment, reduce competitiveness and create uncertainty and inefficiency (Detotto and Otranto (2010)). Crime not only leads to both material and immaterial costs for those who have become victimised but also burdens society as a whole with both material and immaterial costs. This paper investigates the effect of local crime on mental well-being in Germany, using data from the German Socio-Economic Panel (SOEP) and a novel data set constructed from official police crime statistics, covering both counties and urban district, for the time period between 1994 and 2012. It not only extends the literature on the relationship between crime and well-being by investigating this effect for the first time for Germany, but also by investigating it for different types of crime, for different measures of well-being, and for a considerably longer time span than related studies.

So far, the related literature has investigated the effect of crime on well-being both between (see, for example, Arvin and Byron (2012)) and within (see, for example, Katz et al. (2001)) countries. While between-country studies have focused mostly on the relationship between economic (financial) crime and well-being, suggesting that countries with relatively higher levels of corruption, organised crime, and property rights violation report relatively lower levels of life satisfaction, within-country studies have focused mostly on the negative impact of local crime on wages (see Braakmann (2008)), and on property prices. ${ }^{1}$ Our paper is more closely related to a recent strand of literature investigating the effect of local area crime on well-being, measured in terms of life satisfaction or mental health (see Cornaglia and Leigh (2011) and Dustmann and Fasani (2013)). Although property prices might be indirectly linked to life satisfaction or mental health, this stream of literature is new in the sense that it provides a direct link between local crime and well-being. So far, no study in this stream of literature has been conducted in the context of Germany. As such, this paper contributes to the literature in the following ways. First, it is the first paper to quantify the effect of local crime on well-being in Germany. Second, it investigates this effect for different types of crime. In doing

\footnotetext{
${ }^{1}$ Regardless of whether property prices are measured by contingent valuation methods based on stated preferences (Cohen et al. (2004); Atkinson et al. (2005)) or by hedonic price models based on revealed preferences (Gibbons (2004); Linden and Rockoff (2008)), crime rates are found to depress property prices.
} 
so, it uses a novel data set constructed from official police crime statistics, covering both counties and urban districts, thus extending existing data sets in terms of both spatial areas and time periods. Third, its focus lies not only with life satisfaction but it also considers other measures of well-being, such as satisfaction with the home or worriedness.

The main findings of this paper are that the different types of crime do not affect well-being equally. The total crime rate has a statistically significant, negative effect on unconcern about crime and life satisfaction and increases the frequency of being worried, but has no effect on satisfaction with the domicile. In particular, a $1 \%$ increase in the total crime rate decreases residents' life satisfaction by 0.043 standard deviations. When splitting up crime into violent crime, property crime, and other crime, we find that the negative effect of crime on well-being is almost solely driven by the local violent crime rate. In particular, a $1 \%$ increase in the violent crime rate causes a 0.12 standard deviation decrease in life satisfaction of survey respondents.

This paper is important from a policy perspective as it allows quantifying the reduction in well-being which follows from local crime. ${ }^{2}$ In turn, this allows quantifying the willingness of local residents to pay for a higher police presence, both at the county-level and at the state-level. While the analysis is restricted to Germany, the obtained results are transferable to countries which have a similar institutional framework, in particular when it comes to jurisdiction and jurisprudence.

The rest of this paper is organised as follows. Section 2 reviews the related literature and derives hypotheses about the effect of local area crime on well-being. Section 3 describes the data collection and data sampling process as well as descriptive statistics of the final sample. Section 4 introduces the empirical model, while the obtained results are presented in Section 5. The final section concludes.

\section{Literature Review}

Starting with the seminal study by Becker (1968), the determinants and effects of crime have been investigated in a number of contexts. ${ }^{3}$

\footnotetext{
${ }^{2}$ Although it has been argued that it is difficult to quantify well-being, "there is a large body of evidence on the reliability and validity of measures of subjective well-being" (OECD (2013), p.12).

${ }^{3}$ Similarly, the determinants and effects of life satisfaction have been investigated in a number of contexts. See Frey (2010) for a review.
} 
Regarding the determinants of the crime level, for example, Camacho and Mejía (2013) investigate the effect of conditional cash transfers on crime, finding that property crime decreases significantly during the days following cash transfers to families in poor regions. Regarding the effects of the crime level, for example, Braakmann (2008) finds that the local crime level affects regional wages. The literature on the effect of crime on well-being, however, is scant. Not surprisingly, the majority of studies find a negative relationship between local crime and well-being of crime victims. For example, Powdthavee (2005) uses South-African household survey data to investigate the relationship between local crime and satisfaction with life, finding that victims are relatively less satisfied with their life than non-victims and that life satisfaction is relatively higher where local crime is low. Interestingly, the latter also holds for non-victims. For Switzerland, Staubli et al. (2014) show that victims of crimes are less satisfied with life. Davies and Hinks (2010) show that women in particular suffer from subjective feelings of insecurity due to local crime. As such, crime can inflict both direct and indirect costs on society. While direct costs are relatively easy to measure, involving, inter alia, the monetary costs inflicted on victims and the costs of police, prosecution, and prevention, indirect costs are relatively hard to measure, involving, inter alia, the fear and anxiety inflicted on victims and non-victims which leads to changes in behaviours and choices (Hamermesh, 1999; Braakmann, 2012). Thus, both direct and indirect costs of local crime can reduce the well-being of local residents. ${ }^{4}$

Rather than focusing on crime victims only, this paper analyses the effect of crime on the entire society. Even individuals who have not been victimised may suffer from the perceived crime surrounding them. While changes in crime rates can be directly achieved by policy, changes in perceptions and fears of crime may take place only over a long time period.

The two within-country studies which are closest to this paper are Dustmann and Fasani (2013) and Cornaglia and Leigh (2011). ${ }^{5}$ Dustmann and Fasani (2013) investigate the effect of local crime on mental well-being in the United Kingdom, using the British Household Panel Study (BHPS)

\footnotetext{
${ }^{4}$ For more evidence on the relationship between well-being and fear of local crime rather than local crime itself, see Mawby (1982), Ferraro (1995), Hale (1996), Smith and Torstensson (1997), Ross and Mirowsky (2001), Green et al. (2002), Whitley and Prince (2005), Chadee et al. (2007), Stafford et al. (2007), and Jackson and Stafford (2009).

${ }^{5}$ Other within-country studies which are conceptually close but use cross-section instead of panel data are Katz et al. (2001), Kling et al. (2007), and Ludwig et al. (2012).
} 
for the time period between 2002 and 2008. They demonstrate that local crime has a sizeable negative effect on mental health, mainly related to depression and anxiety, and that this effect is driven by property crime and its size is larger for women when compared to men. Cornaglia and Leigh (2011) investigate the effect of local crime on mental well-being in Australia, using the Household, Income, and Labour Dynamics Survey in Australia (HILDA) for the time period between 2001 and 2006. They also demonstrate that local crime has a negative effect on mental health, finding that the size of this effect is larger for violent crime when compared to non-violent crime. The authors show that press coverage of local crime enhances this effect.

Our paper sets these two studies in a new context, namely the context of Germany. It is the first study to analyse the effect of local crime on well-being in Germany, in particular on four broad areas of well-being, including satisfaction with life and satisfaction with the domicile, worries about crime in Germany, and the frequency of being worried. This paper uses a novel crime data set constructed from official police crime statistics, covering both counties and urban districts, and extending existing data sets to cover all German counties and a longer time period. ${ }^{6}$ While Braakmann (2008) uses the same crime data source for a shorter time period when investigating the effect of local crime on labour market outcomes, we extend our data set to range from 1994 to 2012.

The contributions of this paper are thus (i) to quantify the effect of local area crime on well-being in a German context and (ii) to allow for heterogeneous effects for different types of crime. Crime is thought to affect mental well-being in three dimensions: It results in an increased fear of being victimised, in a reduced sense of freedom due to behavioural limitations and changes, and in increased costs of keeping oneself and one's belongings safe.

Against the background of findings by Cornaglia and Leigh (2011) and Dustmann and Fasani (2013), three hypotheses on the effect of local crime on well-being will be tested:

H.1 The effect of local crime on well-being is negative. Individuals living in areas with high crime rates are less happy and satisfied than individuals living in areas with low crime and vice versa.

\footnotetext{
${ }^{6}$ The European Regional Crime Database is the most advanced data set suitable for between-country and within-country comparisons of crime in Europe. However, in the case of Germany, it is limited to the time period between 1980 and 1998 and omits the state of Thuringia. Therefore, we employ a new dataset instead.
} 
H.2 The effect of local crime on well-being differs for different measures of well-being.

H.3 The effect of local crime on well-being differs for different types of crime. Violent crimes have a larger impact than property crimes. Furthermore, crimes which have no effect on third parties have no effect on societal well-being.

\section{Data}

\subsection{Well-Being}

We use survey data from the German Socio-Economic Panel (SOEP) for the time period between 1994 and 2012. The SOEP is a comprehensive and representative longitudinal survey-based study of private households in Germany, covering almost 11,000 households and 20,000 individuals every year. It provides information on all household members, including Germans living in the ten old and six new federal states, foreigners, and recent immigrants (Wagner et al., 2007). Most importantly, it provides information on the post codes of the places of residence of individuals, allowing us to match individual and household characteristics with data on crime and the local economic environment. As such, the SOEP is not only representative of individuals living in Germany, but also provides the necessary geographical reference points for our analysis.

For comparability to the literature, we select a set of dependent variables which covers four broad areas of well-being, including satisfaction with life and satisfaction with the domicile, worries about crime in Germany, and the frequency of being worried. ${ }^{7}$ Firstly, we select satisfaction with life and satisfaction with the domicile as indicators of life satisfaction in general and life satisfaction in a particular domain which is presumed to be more prone to local crime. The two indicators are obtained from eleven-point single-item scales in which individuals are asked, respectively, "How satisfied are you with your life, all things considered?" and "How satisfied are you with your place of dwelling?". 8 Secondly, we select unconcern about crime

\footnotetext{
${ }^{7}$ Conceptually, satisfaction with life is defined as cognitive evaluations of the circumstances of life.

${ }^{8}$ Notably, the life satisfaction approach to value the effect of local crime on residential well-being is not entirely free of methodological issues. For example, for data on the self-reported subjective well-being of individuals to constitute a valid approximation
} 
in Germany as an indicator of worries which is conceptually closest to global crime. The indicator is obtained from a three-point single-item scale which asks "What is your attitude towards the following areas - are you concerned about them? Crime in Germany". Thirdly, we select frequency of being unconcerned as an indicator of the intensity of worries. ${ }^{9}$ The indicator is obtained from a five-point single-item scale in which individuals are asked, "Please indicate how often or rarely you experienced this feeling in the last four weeks. How often have you felt worried?". We rescale all these well-being indicators to range from 0 to 1 , such that high values imply high satisfaction with life and the domicile, low worriedness, and low frequency of being worried and low values imply low satisfaction and high worriedness. Furthermore, we standardise them by their standard deviation to ease interpretation. ${ }^{10}$

Descriptive statistics can be found in Table 3.2, and maps of the regional variation in well-being can be found in Appendix B (see Figures B.1, B.2, B.3, B.4).

\subsection{Crime}

Similar to Braakmann (2008), we use official police crime statistics, covering both counties and urban districts. In Germany, there are 295 counties (Landkreise) and 107 urban districts (kreisfreie Städte), distributed over sixteen federal states (Bundesländer). For the period 2009 to 2012, crime statistics on the county-level are available from the Federal Criminal Police Office (Bundeskriminalamt) ${ }^{11}$, while for the period 1994 to 2009 these data had to be collected from each of the sixteen State Offices of Criminal Investigations (Landeskriminalämter) ${ }^{12}$.

of their welfare, they have to be at least ordinal in character. Moreover, the micro-econometric life satisfaction function which relates the self-reported subjective well-being of individuals to local crime has to be correctly specified. However, these requirements are typically met in practice. See Welsch and Kühling (2009) for a more detailed review.

${ }^{9}$ This indicator has been collected from 2007 onwards; therefore, it covers only a relatively short time period compared to the other measures of well-being.

${ }^{10}$ See Appendix A for a more detailed overview of the dependent variables.

${ }^{11}$ We would like to thank Brigitte Geide at the Bundeskriminalamt for the provision of crime data for the period 2009 to 2012.

${ }^{12} \mathrm{We}$ would like to thank the Landeskriminalämter Baden-Württemberg, Bayern, Berlin, Brandenburg, Bremen, Hamburg, Hessen, Mecklenburg-Vorpommern, Niedersachsen, Nordrhein-Westfalen, Rheinland-Pfalz, Saarland, Sachsen, 
For the 295 counties and 107 urban districts we have detailed data for different types of crimes, both of a violent and non-violent nature. In particular, we know the number of total criminal offences, as well as the number of car thefts, thefts of goods from within vehicles, crimes involving narcotics and drugs, cases of breaking and entering, violent crimes with physical harm done, crimes with aggravated assault, murders, robberies, crimes involving material and property damage, cases of obtaining benefits by devious means (colloquially known as fare-dodging), as well as cases involving street criminality. For these crime types we calculate a frequency ratio showing how many offences per 100,000 inhabitants took place. In line with the methodology applied by Dustmann and Fasani (2013) we then group the crimes as follows: crimes which involve theft or damaging of property are classified as property crimes, while crimes with physical harm done are classified as violent crimes. All remaining crimes which have no effect, neither in terms of physical harm done nor property harmed, are classified as other crimes. Unlike Dustmann and Fasani (2013) and Cornaglia and Leigh (2011) we do not only focus on metropolitan areas but use data on all German counties and cities. Table 3.1 shows the classifications of the crime variables and provides some descriptive statistics, while maps displayed in Appendix B show the regional variation in crime rates (see Figures B.5, B.6, B.7).

The maps shown in Appendix B show that crime rates are higher for more populated areas and in Northern Germany. Property crimes and other crimes are the most frequent types of crime. On average, 3 murders per 100,000 inhabitants occurred in our sample period. Misdemeanours such as fare-dodging occurred much more frequently, with an average of 1066 occurrences per 100,000 inhabitants.

A note on the dark figure of crime. Crime data are generally problematic because only the reported cases of crime will show up in the official statistics. The difference between the official and the actual levels of crime is called the dark figure. In certain cases, crimes are not reported to the police, for example because the general public believes they are trifles, because victims are too embarrassed to tell, or because of low trust in the justice system. In addition, some types of crime are more likely to be reported than others. However, since we believe that there are no systematic differences

Sachsen-Anhalt, Schleswig-Holstein, and Thüringen for the provision of county-level crime data for years prior to 2009 . 


\begin{tabular}{lrrrrr}
\hline Variable & $N$ & Mean & Std. Dev. & Min. & Max. \\
\hline Total crimes & 255918 & 7505.26 & 3386.26 & 967.99 & 59400.33 \\
Violent crimes & 152852 & 527.97 & 343.62 & 87.61 & 2435.03 \\
Assault & 263322 & 319.02 & 275.12 & 0 & 1773.06 \\
Crime of violence & 263837 & 244.20 & 137.12 & 26.55 & 1769.48 \\
Street criminality & 263360 & 2050.61 & 1194.50 & 148.18 & 9866.73 \\
Murder & 154310 & 3.06 & 2.16 & 0 & 22.00 \\
Robberies & 263691 & 64.69 & 50.71 & 1.22 & 596.33 \\
Property crimes & 260926 & 3688.29 & 1964.07 & 357.31 & 17454.12 \\
Breaking and entering & 263114 & 185.21 & 152.12 & 2.28 & 1599.20 \\
Car theft & 261465 & 64.69 & 65.41 & 0 & 2331.54 \\
Property damage & 263555 & 865.06 & 334.74 & 0 & 4967.67 \\
Theft from within cars & 262816 & 528.72 & 434.92 & 5.13 & 3840.60 \\
Other crimes & 162921 & 1628.44 & 1181.50 & 92.85 & 9198.97 \\
Fare dodging & 163017 & 1066.93 & 735.18 & 0 & 7378.61 \\
Fraud & 263785 & 239.70 & 370.82 & 0 & 3480.60 \\
Drug abuse & 263085 & 305.52 & 203.95 & 5.05 & 2389.07 \\
\hline
\end{tabular}

Table 3.1: Descriptive statistics for several measures of crime (covering the time period 1994 to 2012) contain the number of observations, the mean, standard deviation, minimum and maximum value. The frequency ratio is the number of crimes per 100,000 inhabitants. Regressions use logged frequency ratios, but here absolute frequency ratios are displayed.

in dark figures across counties, we believe that this problem is negligible. Furthermore, it is likely that the dark figure is relatively low in more developed countries because of a more efficient judicial system.

An alternative to official crime statistics would be to use data on victimisation or self-reporting. However, we use official crime statistics for two reasons. First, we wish to determine the effect of local crime on the well-being of the general public, not just those who have become victim to crime. Second, for those who have not become victims of crime it is likely that their perception of the crime level aligns with official crime statistics as the general public is unlikely to perceive crimes that the police force does not perceive; therefore, we view the dark figure of crime as negligible from now on. 


\subsection{Control variables}

To account for confounding factors, we select a set of independent variables from the demographic and human capital characteristics, as well as economic conditions and household characteristics of individuals, in addition to macroeconomic characteristics of counties as control variables which have been found to affect the dependent variables in the literature. ${ }^{13}$ Descriptive statistics for the considered individual-specific and region-specific control variables (as well as for the well-being variables) are displayed in Table 3.2 .

All individual-specific variables are obtained from the SOEP. In line with Blanchflower and Oswald (2004), we control for age, gender, relationship status, education level, employment status, and household income. Certain region-specific variables are obtained from the "Regionaldatenbank Deutschland", a data base offering statistics at the county-level. In particular, demographic variables, the education level, the population density, and unemployment rates are included, in line with Blanchflower and Oswald (2004). Furthermore, following Tavits (2008), we use regional average household income provided by the SOEP to control for county-specific wealth. The SOEP also provides some other regional statistics; we use the employment rate, the share of foreigners, and the population. As a proxy for the efficiency of the police force and the law, we use the clearance ratio for each county, which is the number of cases solved divided by the total number of cases known to the police. Data come from the official police crime statistics. Like Delken (2008), we control for residency in the Eastern and Western federal states.

As displayed in Table 3.2, the average age in our sample is 47 years. About $64 \%$ of the sample reports being married; around $12 \%$ have a disability. Around $26 \%$ in our sample have tertiary education, $41 \%$ are full-time employed. On average, $4.3 \%$ of the respondents are unemployed. Taken together, these key demographic characteristics suggest that the final sample is representative for Germany.

\subsection{Data merging}

Merging individual survey and regional data. Individuals in the SOEP are uniquely identified by a person number and can thus be tracked over time. The individuals' locations are given by the post codes of their places of

${ }^{13}$ See Frey (2010) for a detailed review. 


\begin{tabular}{lrrr}
\hline Variable & $N$ & Mean & Std. Dev. \\
\hline Satisfaction w/ domicile & 313153 & 3.921 & 1 \\
Unconcern abt. crime & 313006 & 0.971 & 1 \\
Satisfaction w/ life & 314175 & 3.881 & 1 \\
Frq. unconcerned & 92586 & 4.095 & 1 \\
Married & 315019 & 0.641 & 0.480 \\
Divorced & 315019 & 0.066 & 0.248 \\
Widowed & 315019 & 0.063 & 0.243 \\
Disabled & 313287 & 0.120 & 0.325 \\
Secondary educ. & 308197 & 0.535 & 0.499 \\
Tertiary educ. & 308197 & 0.259 & 0.438 \\
Full-time job & 315021 & 0.411 & 0.492 \\
Part-time job & 315021 & 0.098 & 0.298 \\
Self-employed & 299241 & 0.058 & 0.233 \\
Out of labour force & 315021 & 0.425 & 0.494 \\
In education & 308197 & 0.015 & 0.120 \\
Maternity leave & 315026 & 0.055 & 0.229 \\
Unemployed & 314280 & 0.069 & 0.254 \\
Child in HH & 401252 & 0.380 & 0.485 \\
log HH income & 314944 & 10.294 & 0.623 \\
Area case closing rate & 258301 & 54.534 & 7.378 \\
Employment rate & 329013 & 49.164 & 3.889 \\
Area av. HH income & 331126 & 1405.646 & 223.201 \\
Area pop. share young & 214367 & 74.503 & 23.557 \\
Area pop. share foreign & 213024 & 8.267 & 5.265 \\
\hline
\end{tabular}

Table 3.2: Individual-specific and regional characteristics. Descriptive statistics (covering the time period 1994 to 2012) contain the number of observations, the mean and standard deviation. 
residence. Crime data as well as regional statistics are available at the county-level, identified by a 5-digit county code. In order to merge the datasets, we assign the correct 5-digit county code to the SOEP survey respondents and we account for changing county codes over time.

Consistency of crime data over time. Different types of crime are uniquely identified by a delict-key. Because of reforms in our period of interest, delict-keys change from 4-digit to 6-digit. We convert these to ensure a consistent data merge.

\section{Empirical Model}

We use panel data ranging from 1994 to 2012 for German survey respondents, as well as the individual-specific and region-specific characteristics described in Section 3 to determine whether different types of crime have an effect on different measures of well-being.

We estimate the following regression equation:

$$
W B_{i r t}=\beta_{1} C_{r t-1}+\beta_{2} Z_{r t}+\beta_{3} X_{i t}+\varepsilon_{i r t}
$$

where $W B_{\text {irt }}$ is well-being of survey respondent $i$, resident in region $r$ at time $t ; C_{r t-1}$ is the rate of crime (in logarithms) per 100,000 inhabitants in region $r$ at time $t-1 ; Z_{r t}$ are region-specific characteristics for region $r$ at time $t ; X_{i t}$ are individual-specific characteristics of individual $i$ in period $t$, and $\varepsilon_{i r t}$ is an error term.

Furthermore, we capture regional fixed effects. ${ }^{14}$ Standard errors are heteroskedasticity-robust and always clustered at the individual level. ${ }^{15}$ Our main goal is to estimate $\beta_{1}$ in order to quantify the indirect costs of crime.

\section{Results}

Table 5.1 presents the regression results of different measures of well-being (satisfaction with life, satisfaction with the domicile, unconcern about crime in Germany, frequency of being unconcerned) on the lagged, logarithmised frequency ratio of total crime (that is, crimes per 100,000

\footnotetext{
${ }^{14}$ We also ran regressions with individual fixed effects in order to account for moving individuals. The results are almost identical to those presented below.

${ }^{15}$ While the well-being data are technically discrete, we follow Dustmann and Fasani (2013) and estimate a fixed-effects model.
} 
individuals). All well-being measures are scaled on $(0,1)$ such that higher values imply more well-being. Therefore, we expect to find negative coefficients for total crime in all four columns.

Let us first comment on the regression results for the included control variables. Age and its squared term have the expected effects which are in line with the literature (see, for example, (Blanchflower and Oswald, 2004)): well-being reaches its low point around the age of 30; the young and the old are the happiest. Contrary to Stack and Eshleman (1998) we find that being married has no statistically significant effect on any measure of well-being. As Oswald and Powdthavee (2008) we find that being disabled has a significantly negative effect on satisfaction with the domicile and life satisfaction. Women on maternity leave experience higher life satisfaction but at the same time lower satisfaction with the domicile and more worries about crime. Similarly, having a child in the household increases life satisfaction and makes individuals worry less often but it increases the intensity of worries about crime. ${ }^{16}$ Having a full-time job increases life satisfaction, while being unemployed decreases life satisfaction. Higher household income increases well-being in almost all aspects. Concerning the area-specific control variables, an efficient police force (as proxied by the area case closing rate) decreases the frequency of being worried and decreases worries about crime. In addition, good labour market conditions, proxied by the regional employment rate, increase life satisfaction. People are more worried about crime in areas with low average income, though less worried the higher the foreigners' share and the share of young people. Individuals are less satisfied with their domicile the higher the foreigners' share in their area of residence.

\footnotetext{
${ }^{16}$ This result is similar to findings by Halla et al. (2013) who find that parents are more concerned about environmental issues than non-parents.
} 


\begin{tabular}{|c|c|c|c|c|}
\hline & $(1)$ & $(2)$ & $(3)$ & $(4)$ \\
\hline & Satisfaction w/ life & Frq. unconcerned & Satisfaction w/ domicile & Unconcern abt. crime \\
\hline \multirow[t]{2}{*}{ Total crime } & $-0.043^{* *}$ & $-0.059^{* *}$ & -0.032 & $-0.070^{* * *}$ \\
\hline & $(0.038)$ & $(0.035)$ & $(0.138)$ & $(0.003)$ \\
\hline \multirow[t]{2}{*}{ Age } & $-0.012^{*}$ & $-0.063^{* * *}$ & 0.011 & $0.042^{* * *}$ \\
\hline & $(0.053)$ & $(0.009)$ & $(0.121)$ & $(0.000)$ \\
\hline \multirow[t]{2}{*}{$\mathrm{Age}^{2}$} & $-0.00020^{* * *}$ & 0.00034 & $-0.00018^{* * *}$ & -0.000045 \\
\hline & $(0.000)$ & $(0.106)$ & $(0.001)$ & $(0.440)$ \\
\hline \multirow[t]{2}{*}{ Married } & 0.024 & -0.12 & -0.018 & 0.026 \\
\hline & $(0.554)$ & $(0.204)$ & $(0.698)$ & $(0.563)$ \\
\hline \multirow[t]{2}{*}{ Divorced } & $0.11^{*}$ & -0.16 & -0.087 & 0.023 \\
\hline & $(0.079)$ & $(0.278)$ & $(0.169)$ & $(0.720)$ \\
\hline \multirow[t]{2}{*}{ Widowed } & -0.053 & -0.060 & 0.017 & 0.023 \\
\hline & $(0.517)$ & $(0.782)$ & $(0.803)$ & $(0.727)$ \\
\hline \multirow[t]{2}{*}{ Disabled } & $-0.12^{* * *}$ & -0.0014 & $-0.077^{* * *}$ & 0.039 \\
\hline & $(0.000)$ & $(0.983)$ & $(0.002)$ & $(0.156)$ \\
\hline \multirow[t]{2}{*}{ Secondary educ. } & -0.029 & 0.15 & $-0.12^{* *}$ & -0.0054 \\
\hline & $(0.498)$ & $(0.149)$ & $(0.024)$ & $(0.912)$ \\
\hline \multirow[t]{2}{*}{ Tertiary educ. } & $-0.14^{* *}$ & 0.19 & $-0.15^{* *}$ & 0.072 \\
\hline & $(0.039)$ & $(0.278)$ & $(0.043)$ & $(0.333)$ \\
\hline \multirow[t]{2}{*}{ Full-time job } & $0.061^{* *}$ & -0.039 & -0.029 & -0.038 \\
\hline & $(0.042)$ & $(0.535)$ & $(0.370)$ & $(0.220)$ \\
\hline \multirow[t]{2}{*}{ Part-time job } & 0.015 & -0.012 & -0.0088 & -0.047 \\
\hline & $(0.582)$ & $(0.825)$ & $(0.766)$ & $(0.109)$ \\
\hline \multirow[t]{2}{*}{ Self employed } & 0.052 & -0.031 & -0.028 & 0.035 \\
\hline & $(0.152)$ & $(0.642)$ & $(0.439)$ & $(0.345)$ \\
\hline \multirow[t]{2}{*}{ Out of labour force } & -0.011 & -0.054 & -0.0086 & -0.016 \\
\hline & $(0.676)$ & $(0.292)$ & $(0.754)$ & $(0.531)$ \\
\hline \multirow[t]{2}{*}{ In education } & 0.025 & -0.012 & 0.036 & 0.030 \\
\hline & $(0.619)$ & $(0.900)$ & $(0.518)$ & $(0.600)$ \\
\hline \multirow[t]{2}{*}{ Maternity leave } & $0.078^{* *}$ & -0.021 & $-0.11^{* *}$ & $-0.075^{* *}$ \\
\hline & $(0.030)$ & $(0.787)$ & $(0.016)$ & $(0.047)$ \\
\hline \multirow[t]{2}{*}{ Unemployed } & $-0.33^{* * *}$ & $-0.11^{*}$ & -0.014 & -0.044 \\
\hline & $(0.000)$ & $(0.059)$ & $(0.645)$ & $(0.109)$ \\
\hline \multirow[t]{2}{*}{ Child in $\mathrm{HH}$} & $0.044^{* *}$ & $0.17^{* * *}$ & 0.027 & $-0.051^{* *}$ \\
\hline & $(0.035)$ & $(0.001)$ & $(0.210)$ & $(0.021)$ \\
\hline \multirow[t]{2}{*}{$\mathrm{HH}$ income } & $0.094^{* * *}$ & $0.084^{* * *}$ & $0.064^{* * *}$ & 0.0045 \\
\hline & $(0.000)$ & $(0.006)$ & $(0.000)$ & $(0.764)$ \\
\hline \multirow[t]{2}{*}{ East Germany } & -0.76 & -0.30 & -0.38 & -0.24 \\
\hline & $(0.104)$ & $(0.613)$ & $(0.370)$ & $(0.490)$ \\
\hline \multirow[t]{2}{*}{ Area case closing rate } & 0.0015 & $0.0085^{* *}$ & 0.0013 & $0.0057^{* * *}$ \\
\hline & $(0.279)$ & $(0.011)$ & $(0.350)$ & $(0.000)$ \\
\hline Area employment rate & $0.011^{* * *}$ & 0.014 & 0.00074 & $0.037^{* * *}$ \\
\hline & $(0.000)$ & $(0.324)$ & $(0.826)$ & $(0.000)$ \\
\hline Area av. HH income & -0.000064 & 0.00014 & 0.00012 & $-0.00052^{* * *}$ \\
\hline & $(0.599)$ & $(0.684)$ & $(0.391)$ & $(0.000)$ \\
\hline Area pop. share young & 0.000058 & 0.00039 & -0.00010 & $0.00046^{* * *}$ \\
\hline & $(0.728)$ & $(0.223)$ & $(0.522)$ & $(0.008)$ \\
\hline Area pop. share foreign & 0.0032 & 0.00094 & $-0.035^{* * *}$ & $0.017^{* * *}$ \\
\hline & $(0.618)$ & $(0.956)$ & $(0.000)$ & $(0.005)$ \\
\hline Area population & $0.069^{* *}$ & 0.17 & 0.019 & -0.0056 \\
\hline & $(0.044)$ & $(0.184)$ & $(0.666)$ & $(0.885)$ \\
\hline$R^{2}$ & 0.033 & 0.0061 & 0.0057 & 0.024 \\
\hline$N$ & 56211 & 31056 & 56079 & 56077 \\
\hline
\end{tabular}

Table 5.1: The effect of total crime on different measures of well-being. All well-being measures are scaled such that low values mean low well-being and high values meaning high well-being. Crime, the logged frequency ratio, is lagged by one year. All regressions include regional fixed effects and standard errors are clustered at the individual level. A constant is included but not displayed. 
Since we are hypothesising that the effect of local crime on well-being is negative, we expect a negative coefficient of local crime for all regressions shown in Table 5.1. Indeed, we observe negative and statistically significant coefficients for the number of total crimes when the dependent variables are life satisfaction, the frequency of being unconcerned, and unconcern about crime. Thus, the first hypothesis (H.1), stating that the effect of local crime on well-being is negative, appears to be largely confirmed. While the effect of total crime on satisfaction with the domicile is also negative, it is not statistically significant. In fact, this is in line with the second hypothesis (H.2), stating that the effect of local crime on well-being differs for different measures of well-being. Overall, the results presented in Table 5.1 indicate that the total crime rate has a negative effect on all types of well-being. Crime makes individuals more worried and less satisfied. We find this effect not only for urban areas (as Dustmann and Fasani (2013)) but for Germany as a whole. In particular, a $1 \%$ increase in the total crime frequency ratio results in a 0.043 standard deviations fall in life satisfaction. The frequency of being worried increases by 0.059 standard deviations. The coefficient is largest for worriedness about crime, where a $1 \%$ increase in the total crime rate increases the worriedness about crime in Germany by 0.070 standard deviations. It thus appears that individuals translate their observations of the local crime level to their belief about the global crime level.

We are interested to determine which type of crime has the most severe impact on well-being. For this reason, we split up crime into three broad categories: Property crimes, violent crimes, and other crimes. ${ }^{17}$

We expect that the size of the effect of other crimes is lower than the size of the effect of violent crimes and property crimes, and we expect other crimes to have no statistically significant effect on concern about crime since these crimes do not affect respondents.

\footnotetext{
${ }^{17}$ Recall: Property crimes include car thefts, thefts of property from within vehicles, break-ins, and property damage. Violent crimes include murder, robberies, street criminality, crimes of violence, and assault. Other crimes include fraud, drug abuse and possession, and fare evasion in public transport.
} 


\begin{tabular}{|c|c|c|c|c|}
\hline & $(1)$ & $(2)$ & $(3)$ & $(4)$ \\
\hline & Satisfaction w/ life & Frq. unconcerned & Satisfaction w/ domicile & Unconcern abt. crime \\
\hline \multirow[t]{2}{*}{ Violent crime } & $-0.12^{* *}$ & -0.077 & -0.071 & $-0.14^{* *}$ \\
\hline & $(0.047)$ & $(0.698)$ & $(0.251)$ & $(0.035)$ \\
\hline \multirow[t]{2}{*}{ Property crime } & 0.087 & -0.035 & 0.0011 & 0.0062 \\
\hline & $(0.135)$ & $(0.833)$ & $(0.986)$ & $(0.921)$ \\
\hline \multirow[t]{2}{*}{ Other crime } & -0.035 & 0.019 & -0.037 & $0.081^{* *}$ \\
\hline & $(0.283)$ & $(0.888)$ & $(0.279)$ & $(0.028)$ \\
\hline \multirow[t]{2}{*}{ Age } & -0.010 & -0.0099 & 0.016 & $0.050^{* * *}$ \\
\hline & $(0.420)$ & $(0.942)$ & $(0.272)$ & $(0.000)$ \\
\hline \multirow[t]{2}{*}{$\operatorname{Age}^{2}$} & -0.00016 & 0.00021 & -0.000045 & -0.00016 \\
\hline & $(0.108)$ & $(0.761)$ & $(0.680)$ & $(0.135)$ \\
\hline \multirow[t]{2}{*}{ Married } & -0.056 & 0.16 & -0.036 & 0.083 \\
\hline & $(0.441)$ & $(0.627)$ & $(0.652)$ & $(0.321)$ \\
\hline \multirow[t]{2}{*}{ Divorced } & 0.039 & -0.059 & -0.12 & 0.14 \\
\hline & $(0.723)$ & $(0.888)$ & $(0.242)$ & $(0.199)$ \\
\hline \multirow[t]{2}{*}{ Widowed } & $-0.39 * * *$ & -0.68 & -0.097 & 0.033 \\
\hline & $(0.009)$ & $(0.249)$ & $(0.476)$ & $(0.797)$ \\
\hline \multirow[t]{2}{*}{ Disabled } & $-0.13^{* *}$ & 0.016 & $-0.10^{* *}$ & 0.065 \\
\hline & $(0.013)$ & $(0.914)$ & $(0.025)$ & $(0.180)$ \\
\hline \multirow[t]{2}{*}{ Secondary educ. } & -0.036 & 0.18 & -0.0041 & 0.023 \\
\hline & $(0.616)$ & $(0.493)$ & $(0.969)$ & $(0.782)$ \\
\hline \multirow[t]{2}{*}{ Tertiary educ. } & $-0.21^{*}$ & 0.40 & -0.21 & 0.024 \\
\hline & $(0.071)$ & $(0.519)$ & $(0.129)$ & $(0.853)$ \\
\hline \multirow[t]{2}{*}{ Full-time job } & 0.074 & -0.17 & 0.016 & -0.074 \\
\hline & $(0.166)$ & $(0.286)$ & $(0.768)$ & $(0.146)$ \\
\hline \multirow[t]{2}{*}{ Part-time job } & 0.053 & -0.13 & -0.0093 & -0.033 \\
\hline & $(0.273)$ & $(0.328)$ & $(0.856)$ & $(0.486)$ \\
\hline \multirow[t]{2}{*}{ Self employed } & -0.022 & 0.052 & -0.094 & 0.029 \\
\hline & $(0.761)$ & $(0.798)$ & $(0.145)$ & $(0.665)$ \\
\hline \multirow[t]{2}{*}{ Out of labour force } & -0.051 & -0.13 & 0.00079 & -0.065 \\
\hline & $(0.270)$ & $(0.325)$ & $(0.986)$ & $(0.120)$ \\
\hline \multirow[t]{2}{*}{ In education } & -0.089 & 0.017 & 0.020 & 0.0089 \\
\hline & $(0.305)$ & $(0.949)$ & $(0.842)$ & $(0.918)$ \\
\hline \multirow[t]{2}{*}{ Maternity leave } & $0.13^{* *}$ & 0.051 & -0.025 & -0.038 \\
\hline & $(0.030)$ & $(0.814)$ & $(0.752)$ & $(0.545)$ \\
\hline \multirow[t]{2}{*}{ Unemployed } & $-0.27^{* * *}$ & $-0.29^{* *}$ & -0.018 & -0.0077 \\
\hline & $(0.000)$ & $(0.016)$ & $(0.735)$ & $(0.862)$ \\
\hline \multirow[t]{2}{*}{ Child in $\mathrm{HH}$} & $0.081^{* *}$ & 0.15 & 0.023 & -0.065 \\
\hline & $(0.038)$ & $(0.341)$ & $(0.573)$ & $(0.116)$ \\
\hline $\mathrm{HH}$ income & $0.082^{* * *}$ & 0.059 & 0.049 & 0.0011 \\
\hline & $(0.007)$ & $(0.392)$ & $(0.130)$ & $(0.968)$ \\
\hline Area case closing rate & 0.00097 & -0.00017 & 0.0031 & 0.0034 \\
\hline & $(0.641)$ & $(0.988)$ & $(0.172)$ & $(0.158)$ \\
\hline Area employment rate & $0.013^{* *}$ & -0.014 & 0.0067 & $0.025^{* * *}$ \\
\hline & $(0.014)$ & $(0.757)$ & $(0.256)$ & $(0.000)$ \\
\hline Area av. $\mathrm{HH}$ income & 0.000093 & 0.000066 & -0.00025 & -0.00036 \\
\hline & $(0.667)$ & $(0.967)$ & $(0.330)$ & $(0.104)$ \\
\hline Area pop. share young & 0.000061 & $0.0015^{* *}$ & -0.000079 & $0.00082^{* * *}$ \\
\hline & $(0.821)$ & $(0.028)$ & $(0.765)$ & $(0.004)$ \\
\hline Area pop. share foreign & -0.013 & -0.0059 & $-0.057^{* *}$ & $0.031^{* *}$ \\
\hline & $(0.409)$ & $(0.889)$ & $(0.018)$ & $(0.028)$ \\
\hline Area population & $0.15^{*}$ & 0.72 & $0.27^{* *}$ & 0.019 \\
\hline & $(0.091)$ & $(0.274)$ & $(0.026)$ & $(0.850)$ \\
\hline$R^{2}$ & 0.030 & 0.016 & 0.0078 & 0.016 \\
\hline$N$ & 17414 & 6036 & 17354 & 17364 \\
\hline
\end{tabular}

Table 5.2: The effect of different types of crime on different measures of well-being. All regressions include regional fixed effects and standard errors are clustered at the individual level. A constant is included but not displayed. Crime rates are logarithmised frequency ratios. 
Table 5.2 shows the effect of the three crime groups (violent, property, other) jointly on the different measures of well-being (satisfaction with life, frequency of being unconcerned, satisfaction with the domicile, and unconcern about crime in Germany). The results indicate that only violent crimes have a statistically significant and negative effect on some of the well-being measures, while property crime rates have no effect on any well-being measures. While all coefficients for violent crime are negative as hypothesised, the effect of violent crimes is statistically significant only for life satisfaction and unconcern about crime. Individuals worry less about crime in Germany if local area violent crime is low. This coincides with Davies and Hinks (2010) who report that happiness shrinks with a subjective feeling of insecurity. Furthermore, individuals are significantly more satisfied with their lives as crime in their area of residence shrinks. In particular, a $1 \%$ increase in the violent crime frequency ratio results in a 0.12 standard deviation decrease in life satisfaction, and a 0.14 standard deviation decrease in unconcern about crime in Germany.

While Dustmann and Fasani (2013) find that their insignificant coefficient for violent crime is substantially smaller than that for property crimes, we find an opposing effect. In particular, we find that only violent crimes have a negative impact on all measures of well-being, which is statistically significant for life satisfaction and unconcern about crime. Table 5.1 has shown that rising total crime rates in an area of residence causes increased worriedness about crime in Germany at the global level, lower satisfaction with life, and more frequent worries in survey respondents. Table 5.2 has shown that this effect is driven almost exclusively by violent crimes. ${ }^{18}$

\section{Conclusion}

This paper has investigated the effect of local crime on well-being in Germany, using data from the German Socio-Economic Panel (SOEP) and data from a novel data set constructed from official police crime statistics, covering all German counties and urban districts for the time period between 1994 and 2012. It is the first attempt to quantify the effect of local crime on the well-being of local residents in Germany, focusing not on only victims,

\footnotetext{
${ }^{18}$ On the contrary, Dustmann and Fasani (2013) find that "local crime affects mental wellbeing of residents in urban areas, and that the effect is driven mainly by property crime" (p.17).
} 
but on the general population. As such, it is an important contribution to the literature on the intangible effects of local crime.

We find that local crime not only affects satisfaction with life per se, but furthermore affects narrower domains of life satisfaction, such as individuals' worries about crime in Germany, and the frequency of being worried. The overall effect of crime on well-being is dependent on the type of crime as well as the type of well-being measure. This result coincides with findings in related studies for other countries, particularly Cornaglia and Leigh (2011) and Dustmann and Fasani (2013). Overall, we find that the total crime rate in an area of residence has a significantly negative impact on unconcern about crime, life satisfaction, and the frequency of being worry-free. Most importantly, we find that a $1 \%$ increase in total crime decreases life satisfaction by 0.043 standard deviations. This effect is driven almost exclusively by the violent crime rate. In particular, a $1 \%$ increase in the violent crime rate in a particular area of residence decreases life satisfaction of residents by 0.12 standard deviations. Similarly, a $1 \%$ increase in the violent crime rate results in a 0.14 standard deviation increase in respondents' worriedness about crime. This is similar to findings by Cornaglia and Leigh (2011) who observe a stronger impact of violent than non-violent crimes on well-being. Unlike found by Dustmann and Fasani (2013) we do not observe a significant impact of property crimes on any measures of well-being.

It appears that local residents have a clear perception of the level of local crime in their counties and urban districts, which closely correlates with official police crime statistics. Thus, people living in high-crime areas are more worried about crime and also more frequently worried. Interestingly, local crime not only decreases individuals' well-being at the local level, but also increases their worries about crime at the global level, namely in Germany as a whole. Individuals translate their observations at the local level to their beliefs about national crime rates. 
Arvin, M. and L. Byron (2012). Development Aid, Corruption, and the Happiness of Nations: Analysis of 118 countries over the years 1996-2009. Applied Econometrics and International Development 12(2), 69-78.

Atkinson, G., A. Healey, and S. Mourato (2005). Valuing the costs of violent crime: a stated preference approach. Oxford Economic Papers 57(4), 559-585.

Becker, G. S. (1968). Crime and Punishment: An Economic Approach. Journal of Political Economy 76(2), 169-217.

Blanchflower, D. G. and A. J. Oswald (2004). Well-being over time in Britain and the USA. Journal of Public Economics 88(7-8), 1359-1386.

Braakmann, N. (2008). Crime Does Pay (at Least When It's Violent) - On the Compensating Wage Differentials of High Regional Crime Levels. Technical report, University of Lüneburg, Institute of Economics, Working Paper Series 91.

Braakmann, N. (2012). How do individuals deal with victimization and victimization risk? Longitudinal evidence from Mexico. Journal of Economic Behavior \& Organization 84(1), 335-344.

Camacho, A. and D. Mejía (2013). Las externalidades de los programas de transferencias condicionadas sobre el crimen: El caso de Familias en Acción en Bogotá. IDB Publications 80524, Inter-American Development Bank.

Chadee, D., L. Austen, and J. Ditton (2007). The Relationship Between Likelihood and Fear of Criminal Victimization: Evaluating Risk Sensitivity as a Mediating Concept. British Journal of Criminology 47(1), 133-153.

Cohen, M. A., R. T. Rust, S. Steen, and S. T. Tidd (2004). Willingness-to-pay for Crime Control Programs. Criminology 42(1), 89-110.

Cornaglia, F. and A. Leigh (2011). Crime and Mental Wellbeing. CEP Discussion Papers 1049, Centre for Economic Performance, LSE.

Davies, S. and T. Hinks (2010). Crime and Happiness Amongst Heads of Households in Malawi. Journal of Happiness Studies 11(4), 457-476.

Delken, E. (2008). Happiness in shrinking cities in Germany. Journal of Happiness Studies 9(2), 213-218.

Detotto, C. and E. Otranto (2010). Does Crime Affect Economic Growth? Kyklos 63(3), $330-345$.

Dustmann, C. and F. Fasani (2013). The Effect of Local Area Crime on Mental Health. Technical report, IZA Discussion Papers 7711.

Ferraro, K. (1995). Fear of Crime: Interpreting Victimisation Risk. SUNY Press.

Frey, B. S. (2010). Happiness: A Revolution in Economics. The MIT Press.

Gibbons, S. (2004). The Costs of Urban Property Crime. Economic Journal 114(499), 441-463.

Green, G., J. Gilbertson, and M. Grimsley (2002). Fear of Crime and Health in Residential Tower Blocks. European Journal of Public Health 12(1), 10-15.

Hale, C. (1996). Fear of Crime: A Review of the Literature. International Review of Victimology 4(2), 79-150.

Halla, M., F. Schneider, and A. Wagner (2013). Satisfaction with democracy and collective action problems: the case of the environment. Public Choice 155(1), $109-137$.

Hamermesh, D. S. (1999). Crime and the Timing of Work. Journal of Urban Economics 45(2), 311-330. 
Jackson, J. and M. Stafford (2009). Public Health and Fear of Crime: A Prospective Cohort Study. British Journal of Criminology 49(6), 832-847.

Katz, L. F., J. R. Kling, and J. B. Liebman (2001). Moving To Opportunity In Boston: Early Results Of A Randomized Mobility Experiment. The Quarterly Journal of Economics 116(2), 607-654.

Kling, J. R., J. B. Liebman, and L. F. Katz (2007). Experimental Analysis of Neighborhood Effects. Econometrica 75(1), 83-119.

Linden, L. and J. Rockoff (2008). Estimates of the Impact of Crime Risk on Property Values from Megan Law. American Economic Review 98(3), 1103-1127.

Ludwig, J., G. J. Duncan, L. A. Gennetian, L. F. Katz, R. C. Kessler, J. R. Kling, and L. Sanbonmatsu (2012). Neighborhood Effects on the Long-Term Well-Being of Low-Income Adults. Science 337(6101), 1505-1510.

Mawby, R. (1982). Crime and the elderly: a review of British and American research. Current Psychological Research 2(3), 301-310.

OECD (2013). Guidelines on measuring subjective well-being. Technical report, OECD.

Oswald, A. J. and N. Powdthavee (2008). Does happiness adapt? A longitudinal study of disability with implications for economists and judges. Journal of Public Economics 92, 1061 - 1077.

Powdthavee, N. (2005). Unhappiness and Crime: Evidence from South Africa. Economica 72 (3), 531-547.

Ross, C. E. and J. Mirowsky (2001). Neighborhood Disadvantage, Disorder, and Health. Journal of Health and Social Behavior 42(3), 258-276.

Smith, W. R. and M. Torstensson (1997). Gender Differences in Risk Perception and Neutralizing Fear of Crime: Toward Resolving the Paradoxes. British Journal of Criminology 37(4), 608-634.

Stack, S. and J. R. Eshleman (1998). Marital Status and Happiness: A 17-Nation Study. Journal of Marriage and Family 60(2), 527-536.

Stafford, M., T. Chandola, and M. Marmot (2007). Association Between Fear of Crime and Mental Health and Physical Functioning. American Journal of Public Health 97(11), 2076-2081.

Staubli, S., M. Killias, and B. S. Frey (2014). Happiness and victimization: an empirical study for Switzerland. European Journal of Criminology 11, 57-72.

Tavits, M. (2008). Representation, Corruption, and Subjective Well-Being. Comparative Political Studies 41(12), 1607-1630.

Wagner, G., J. R. Frick, and J. Schupp (2007). The German Socio-Economic Panel Study - Scope, Evaluation, and Enhancements. Schmollers Jahrbuch 127(1), 139-169.

Welsch, H. and J. Kühling (2009). Using happiness data for environmental valuation: Issues and applications. Journal of Economic Surveys 23(2), 385-406.

Whitley, R. and M. Prince (2005). Fear of crime, mobility and mental health in inner-city London, UK. Social Science Medicine 61(8), 1678-1688. 


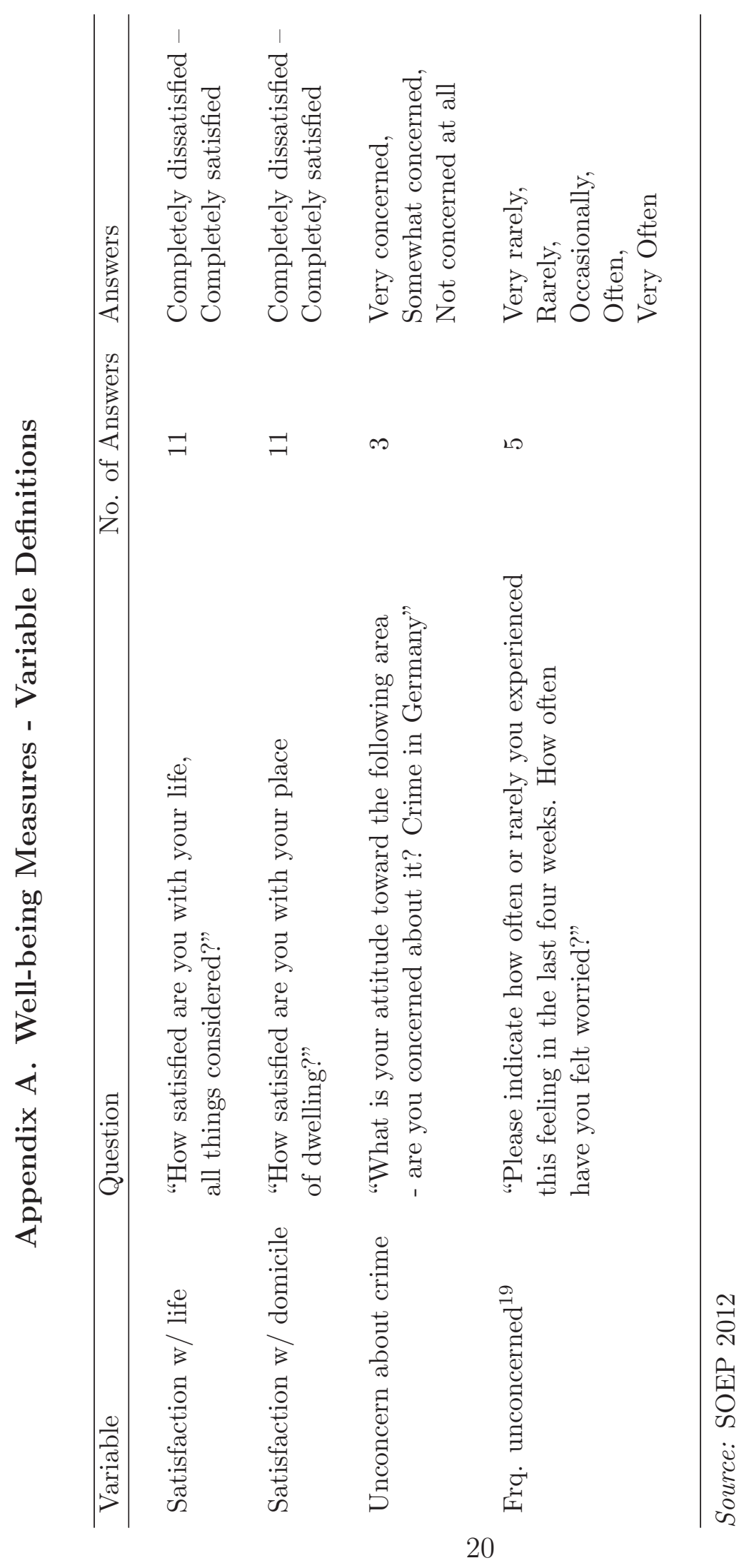

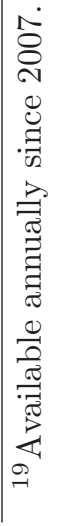




\section{Appendix B. Regional occurrence of well-being and crime}

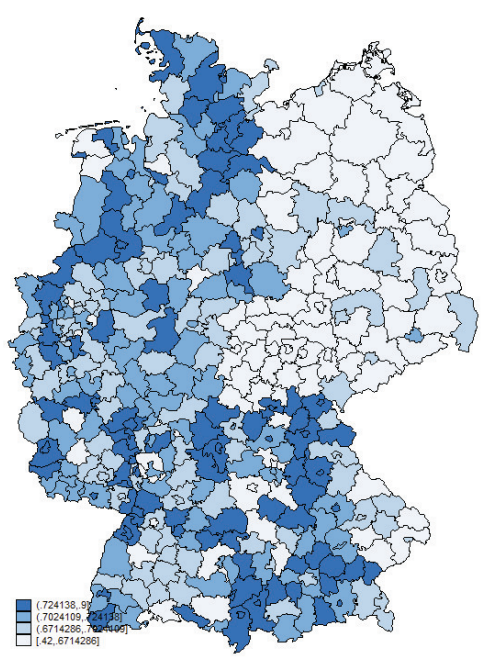

Figure B.1: Mean life satisfaction; average values for 1994 to 2012

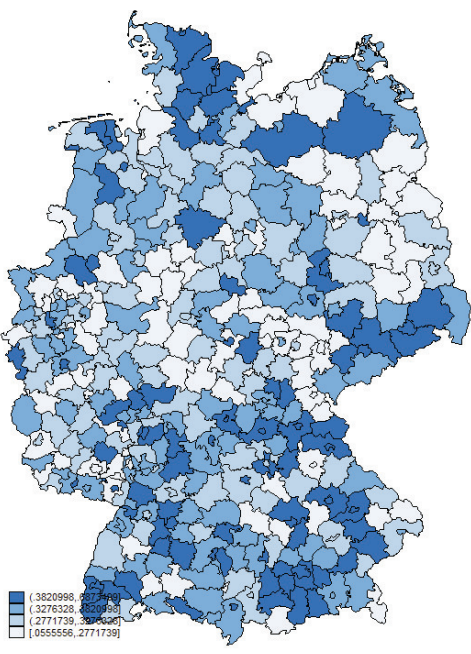

Figure B.3: Mean worriedness about crime in Germany; average values for 1994 to 2012

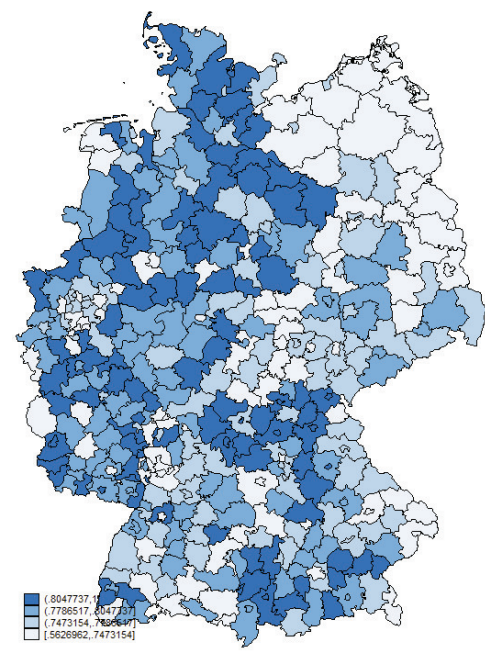

Figure B.2: Mean satisfaction with the domicile; average values for 1994 to 2012

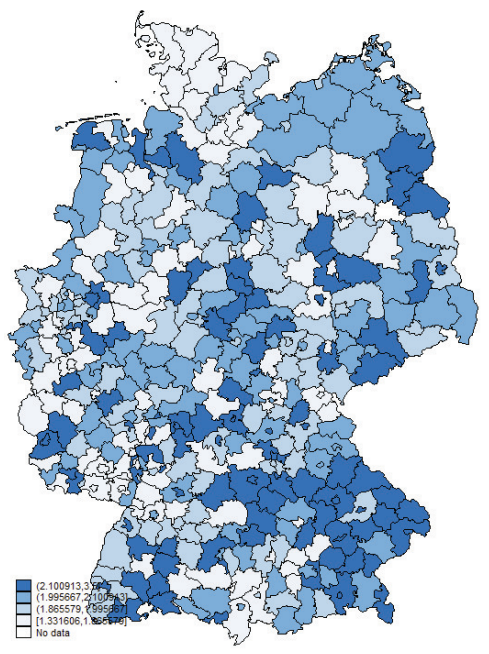

Figure B.4: Mean frequency of being unconcerned; average values for 1994 to 2012 


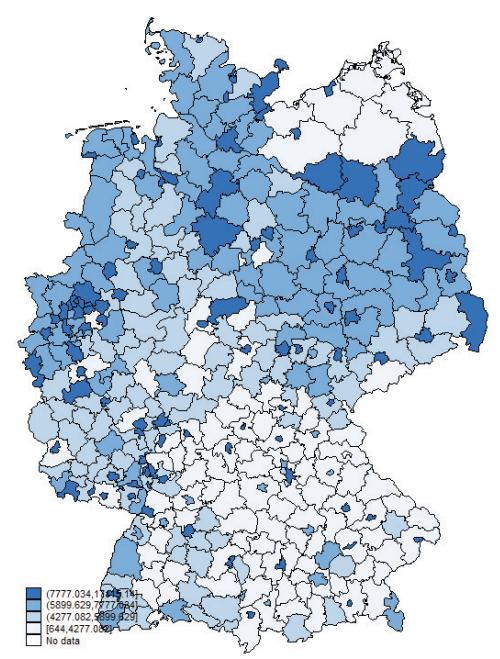

Figure B.5: Total crime rates (frequency ratio); average values for 1994 to 2012

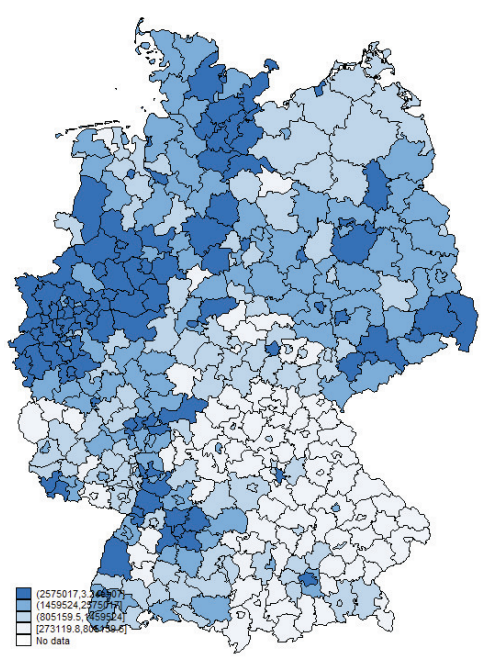

Figure B.6: Property crime rates (frequency ratio); average values for 1994 to 2012

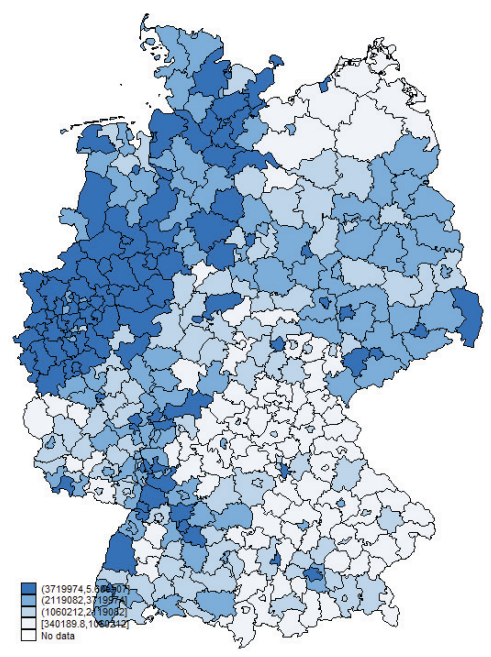

Figure B.7: Violent crime rates (frequency ratio); average values for 1994 to 2012 


\section{Appendix C. Temporal occurrence of well-being and crime}

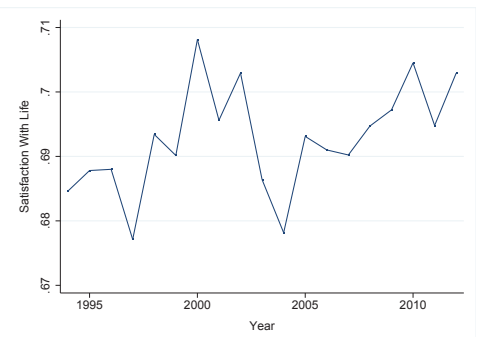

Figure C.8: Mean life satisfaction

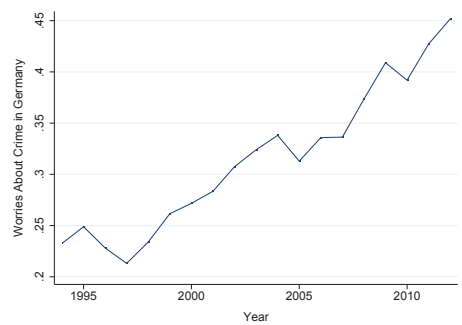

Figure C.10: Mean worriedness about crime in Germany

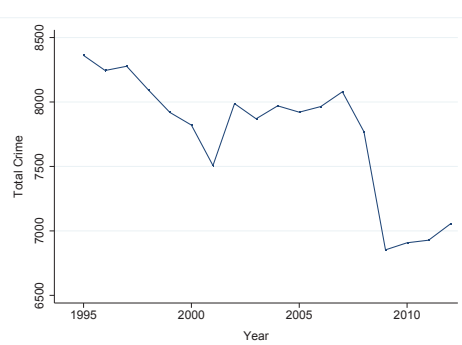

Figure C.12: Total crime rates (frequency ratio)

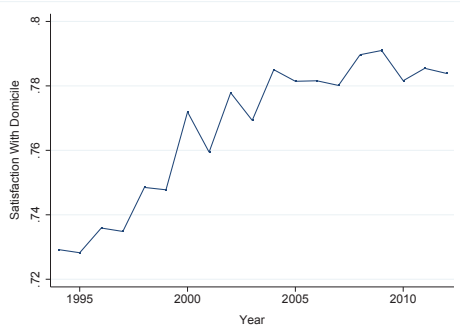

Figure C.9: Mean satisfaction with the domicile

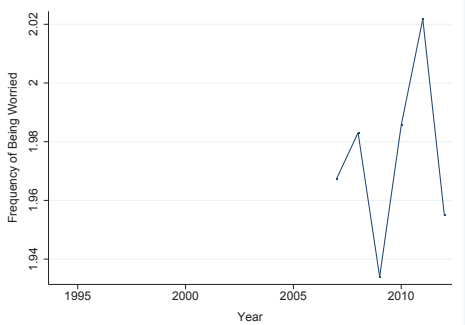

Figure C.11: Mean frequency of being unconcerned

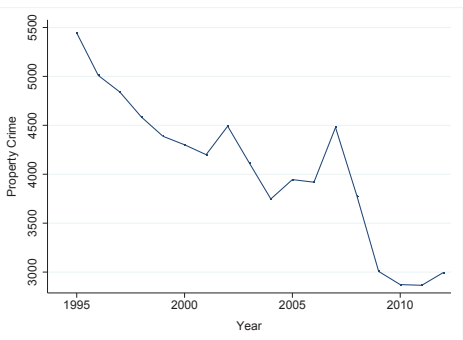

Figure C.13: Property crime rates (frequency ratio) 


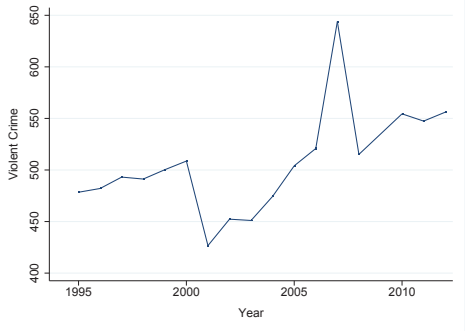

Figure C.14: Violent crime rates (frequency ratio) 